\title{
Tematyzacja przestrzeni jako metoda zarządzania rozwojem lokalnym
}

\section{Przemiany współczesnej turystyki i jej wpływ na rozwój miast i regionów}

Gwałtowny rozwój turystyki masowej nastąpił po II wojnie światowej. W ciągu nieco ponad 60 lat liczba międzynarodowych podróży turystycznych, utrzymując praktycznie nieprzerwany wzrost, zwiększyła się ponad czterdziestokrotnie - z 25 mln w 1950 r. do 278 mln w 1980 r., 528 mln w 1995 r. i $1087 \mathrm{mln}$ w 2013 r. (rys. 1). W połowie XX w. wśród regionów recepcyjnych zdecydowanie dominowały obszary stref umiarkowanej ciepłej i podzwrotnikowej, o cechach klimatu śródziemnomorskiego charakteryzującego się suchym i ciepłym latem oraz wysokim nasłonecznieniem.

Ukształtował się wówczas model turystyki $3 \mathrm{~S}$ bazujący na trzech słowach w języku angielskim - sand, sea, sun. Dla większości podróżujących pierwszym skojarzeniem z turystyką były słońce, plaża i woda. Mniejsze znaczenie przypisywano walorom antropogenicznym, nawet $\mathrm{w}$ regionach posiadających wybitne dzieła sztuki i zabytki architektury pochodzące z różnych okresów historycznych (np. basen Morza Śródziemnego czy obszar Azji Południowo-Wschodniej).

Turystyka powszechnie była traktowana jako oderwana od „realnego” życia, pozbawiona głębi i powagi oraz niewarta poważnego intelektualnego czy naukowego zainteresowania. Niewielu badaczy i naukowców zdawało sobie sprawę, że turystyka stanie się poważnym biznesem i przedmiotem badań. Z czasem jednak

* Uniwersytet Łódzki, Wydział Ekonomiczno-Socjologiczny, Instytut Gospodarki Przestrzennej, Katedra Gospodarki Regionalnej i Środowiska, 90-214 Łódź, Rewolucji 1905 r. nr 39. 


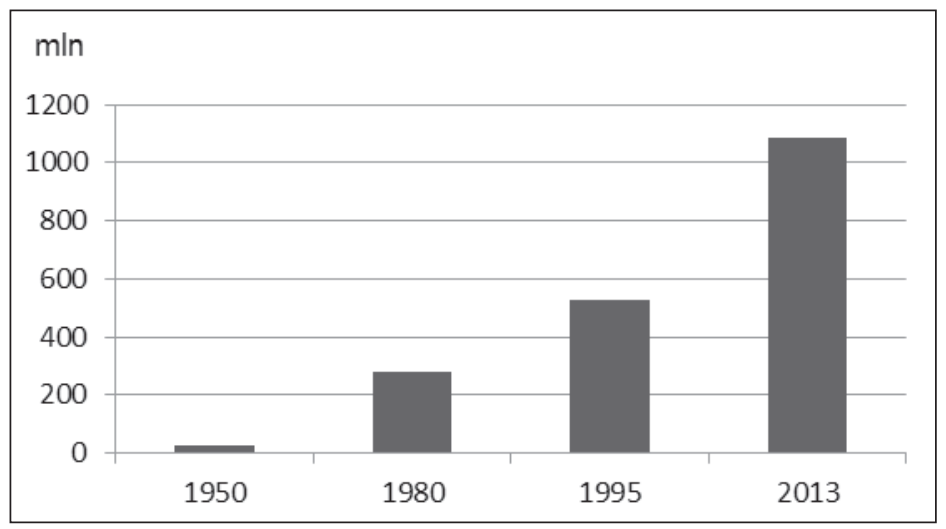

Rysunek 1. Zmiany wielkości międzynarodowego ruchu turystycznego w latach 1950-2013

Źródło: opracowanie własne na podstawie: UNWTO Tourism Highlights 2014 Edition

ikoniczny „amerykański turysta”, zwiedzający kilkanaście krajów zachodnioeuropejskich w ciągu kilku dni, tak sugestywnie i komicznie przedstawiony w filmie pt. Jeśli dziś wtorek to jesteśmy w Belgii (1969), rozpłynął się, a z braku dominującego wzorca stereotyp ,turysty” uległ zróżnicowaniu: rozpadł się na wiele specyficznych typów związanych z narodowościami i stylami podróżowania oraz różnicującymi się tematycznie formami turystyki. Turystykę w kolejnych dekadach uznano za znaczącą sferę współczesnego życia, olbrzymi międzynarodowy biznes, za zjawisko, które dociera nawet do najbardziej odległych regionów świata. Piszący o tym Erik Cohen stwierdził, że „,przemysł turystyczny uważany jest jako [...] główny czynnik sprawczy procesów przyrodniczej, społecznej i kulturowej zmiany, co ujawnia się zwłaszcza w wielu krajach spoza cywilizacji zachodniej" (Cohen, 2011, s. 11).

Począwszy od II wojny światowej kształtuje się globalny produkt turystyczny, powszechnie dostępny, podlegający ciągłemu procesowi postępującej specjalizacji (Kaczmarek, Stasiak i Włodarczyk, 2002, s. 19). Współczesna turystyka staje się coraz bardziej powszechna i dostępna, różnorodna i posegmentowana. Wciąż pojawiają się jej nowe rodzaje. W XXI w. przemysł turystyczny przełamuje kolejne bariery - przykładowo można spodziewać się, że krótkie podróże w kosmos, obecnie dostępne dla nielicznych, uprzywilejowanych finansowo turystów, staną się perspektywicznym kierunkiem przyszłej ekspansji. Prognoza rozwoju turystyki do 2020 r., zawarta w raporcie Światowej Organizacji Turystycznej (WTO), zakłada stopniowe przechodzenie od paradygmatu „3S” do „3E” (entertainment, excitement, education) (Kowalczyk, 2000, s. 263). Coraz częściej pragnienie „rozrywki”, „podniecenia” (lub „ekscytacji”) oraz „edukacji” wygrywa z biernym wypoczynkiem. Współcześni turyści preferują aktywny i poznaw- 
czy wypoczynek kosztem leżenia na piasku. Jednocześnie modyfikacjom ulega model turystyki typu 3S, który nie zanikł, ale nieco stracił na znaczeniu.

Kluczowe dla socjologicznych studiów nad zjawiskiem turystyki od samego początku były pytania ukierunkowane na związki między turystyką a nowoczesnością, a więc pytania o naturę i czynniki kształtujące współczesną turystykę. Dean MacCannell (2000, s. 45), rzucając na początku lat 70. XX w. wyzwanie boorstinowskiej deprecjacji turystyki, stwierdził, że istotą nowoczesnej turystyki jest poszukiwanie autentyczności, którą utraciliśmy w naszym sztucznym, wyobcowanym świecie. Choć nadzieje na to drastycznie tonują np. mistyfikacje, jakich dopuszczają się autochtoni inscenizujący atrakcje turystyczne, chcąc być może „chronić” turystów przed kontaktem z rzeczywistością i nieatrakcyjną prozą swego codziennego życia (Cohen, 2011, s. 15), to nadal poszukiwanie oryginalnych wartości pozostaje kulturowo akceptowanym motywem współczesnych podróży.

Coraz częściej dostrzega się, że skutkiem globalizacji jest zmniejszenie się przyrodniczej i kulturowej różnorodności świata. Postmodernistyczni filozofowie tacy jak Jean Baudrillard (2005, s. 19) twierdzą wręcz, że współczesny świat jest zdominowany przez symulakry ${ }^{1}$ i pozbawiony oryginałów. Co ciekawe, mimo postępującego ujednolicenia świata, turystyka nadal się rozwija. Pojawia się zatem pytanie: dlaczego i w jaki sposób tak ewidentnie spłaszczający się świat pociąga coraz więcej turystów? Można próbować wyjaśniać to dość banalnie rosnącym dobrobytem, który pozwala coraz liczniejszej klasie wyższej i średniej dysponować wyższym dochodem. Nie jest to jednak odpowiedź definitywnie rozwiązująca problem, dlaczego ludzie są skłonni wydawać pieniądze raczej na podróże niż na inne formy aktywności.

Jedną z odpowiedzi na zadane pytanie może być to, że współczesny ,postturysta", określany jako osoba rezygnująca z poszukiwania autentyczności, podejmuje grę i świadomie bawi się pozornością często nieautentycznych atrakcji, zamiast zajmować się ich oryginalnością. Nie goni za różnorodnymi i głębokimi doświadczeniami, wybiera zwiedzanie miejsc, które oferują to, co może przewidywalne, ale jednocześnie jest to ładnie opakowane, sprzedawane w bardziej bezpiecznej i przyjaznej atmosferze, lub po prostu tańsze. Współczesna turystyka, jeżeli nawet rozwija się w sensie ilości podejmowanych podróży, traci swoje cechy szczególne i łączy się ze zwykłym spędzaniem czasu wolnego, codzienną rekreacją i rozrywką. Czysta zabawa, radość i edukacja (niestety często powierzchowna), zgodnie z powyższymi uwarunkowaniami, stają się kulturowo aprobowanymi i wystarczającymi powodami do podróżowania. W „postturystyce” niewiele zostaje z „nadzwyczajności” czyniącej z podróży ucieczkę od codziennego życia. Dotychczasowe zainteresowanie obiektywną autentycznością atrakcji zostało zastąpione rosnącym zainteresowaniem turystów „subiektywnym" doświadczaniem autentyzmu i emocji (Cohen, 2011, s. 8). Poszukiwanie

1 Symulakry to symulacje sztucznych, fantastycznych światów. 
intensywnych, ale ukartowanych i przewidywalnych doświadczeń świata fantazji, dostępnych w przypadku sztucznych atrakcji jest w postmodernistycznym świecie trendem, który wygrywa z poszukiwaniem autentyczności.

Inną przesłanką rozwoju ilościowego turystyki jest powstawanie nowych regionów i miejscowości recepcyjnych, z kolei te tradycyjne ewoluują, modyfikując i wzbogacając swą ofertę. Współcześni turyści nie odżegnują się od wypoczynku w tradycyjnych strefach nadmorskich, od pobytów w modnych uzdrowiskach, od zwiedzania klasycznych zabytków. Poszukują jednak wciąż nowych obszarów i doznań, wkraczają na tereny wiejskie, odwiedzają wszystkie strefy klimatyczne - od równikowej do okołobiegunowej. W ujęciu geograficznym zasoby turystyczne rozumiane jako występujące obiektywnie atrybuty środowiska przyrodniczego i społecznego, które po dokonaniu przez turystę odpowiedniej oceny, w wyniku procesu percepcji mogą stać się faktycznymi walorami (Kowalczyk, 2000, s. 23), są też praktycznie nieograniczone przestrzennie. Każde miejsce może zostać potraktowane jako atrakcja - wszystko podlega bowiem procesom komodyfikacji, czyli utowarowienia (Raszeja, 2008, s. 4). Dzięki takim trendom niemal wszystkie społeczności lokalne i regionalne mają szansę wejść w kontakt z turystami i dostrzec korzyści płynące z rozwoju turystyki, m.in. rozwój przedsiębiorczości, powstawanie nowych miejsc pracy, zmniejszanie bezrobocia, napływ nowych inwestycji. Przekłada się to na wzrost standardu życia, ograniczenie depopulacji regionów etc.

Tabela 1. Najbogatsze miasta i gminy w Polsce w 2013 r.

\begin{tabular}{|l|l|c|c|}
\hline \multicolumn{1}{|c|}{ Kategoria } & \multicolumn{1}{|c|}{$\begin{array}{c}\text { Nazwa miasta } \\
\text { lub gminy }\end{array}$} & $\begin{array}{c}\text { Pozycja } \\
\text { w rankingu }\end{array}$ & $\begin{array}{c}\text { Dochód własny } \\
\text { [w zł/mieszkańca }\end{array}$ \\
\hline Miasta na prawach powiatu & Sopot & 1 & 5909,18 \\
\hline \multirow{5}{*}{ Mniejsze miasta } & Nowe Warpno & 1 & 18913,90 \\
\cline { 2 - 4 } & Krynica Morska & 2 & 13143,45 \\
\cline { 2 - 4 } & Międzyzdroje & 3 & 5832,15 \\
\cline { 2 - 4 } & Dziwnów & 5 & 5337,55 \\
\cline { 2 - 4 } & Karpacz & 6 & 5179,66 \\
\hline \multirow{5}{*}{ Gminy wiejskie } & Rewal & 2 & 11984,41 \\
\cline { 2 - 4 } & Ustronie Morskie & 4 & 6613,55 \\
\cline { 2 - 4 } & Stępnica & 5 & 6207,38 \\
\cline { 2 - 4 } & Mielno & 7 & 5949,15 \\
\hline
\end{tabular}

a - Pominięte zostały wpływy z dotacji celowych, np. fundusze unijne, często mające charakter incydentalny.

Źródło: http://www.wspolnota.org.pl/rankingi/najbogatsze-samorzady/2013/ 
W niektórych regionach świata dochodzi do powstania monokultur turystycznych, np. na Malediwach i Seszelach dochody z turystyki stanowią ok. 1/3 dochodów ogółem (Kurek, 2007, s. 55). Polskim regionom daleko do tak dużego znaczenia turystyki, ale symptomatyczne jest to, że wśród najbogatszych miast i gmin w dużej mierze przodują jednostki posiadające silnie rozwinięte funkcje turystyczne (tab. 1).

\section{Rozwój nowych form turystyki tematycznej}

Rosnące znaczenie rozrywki i przyjemności sensu stricte, a malejące - poszukiwania autentyczności jako zasadniczego motywu podróży, jest przyczyną istotnego wzrostu liczby i technicznego wyrafinowania tworzonych przez człowieka atrakcji turystycznych. Popularność sztucznych obiektów rośnie, zwłaszcza że jakość tych naturalnych staje się niekiedy iluzoryczna. Wzorem dla współczesnych sztucznych atrakcji w typie centrów rozrywki, parków tematycznych, a także masowych imprez kreowanych na całym świecie są obiekty wymyślone i rozpropagowane przez Walta Disneya. Pojawienie się tego typu popularnych instytucji skutecznie imitujących rzeczywistość wpływa na losy klasycznych atrakcji. Znika nagle znaczenie ich immanentnego wydawałoby się atutu, czyli ,atmosfery związanej z miejscem” (placeness). Jednakowoż i nowe atrakcje, pozbawione klimatu oryginalnych miejsc, z czasem potrzebują własnej reputacji w formie sztucznie wytworzonego genius loci, tak jak to stało się w przypadku Las Vegas (Cohen, 2011, s. 17).

Fantazja staje się ważnym motywem podróżowania - turyści uciekają w świat wyobraźni, traktując to jako sposobność doświadczania czegoś radykalnie innego i wyjątkowego w coraz bardziej monotonnym świecie. Jadwiga Warszyńska (2006, s. 90-91) wskazuje na czynniki religijne i związane z nimi legendy oraz mity jako silne bodźce rozwoju turystyki, współcześnie jak i w ujęciu historycznym. Na kulturowo-turystyczne znaczenie mitycznego przekształcania rzeczywistości wskazuje również to, że istnieją liczne obiekty i szlaki turystyczne opierające swe funkcjonowanie o walor w postaci legend literackich, takich jak na przykład: platońska Atlantyda, homerycka opowieść o podróżach Odyseusza, wymyślona przez Chretiena de Troyes legenda o królu Arturze i rycerzach Okrągłego Stołu, a także przenoszone na ekrany kin powieści, np. o Harrym Potterze autorstwa J. K. Rowling czy mówiące o hobbitach i elfach dzieła J. R. R. Tolkiena.

Zbiorowa ekscytacja fantazjami nie jest dominująca i współwystępuje z przeciwstawnymi trendami. Wśród turystów-tradycjonalistów są m.in. plecakowicze (ang. backpackers), którzy odrzucają utarte szlaki turystyczne i stale poszukują słabo dostępnych miejsc, aby doświadczyć tego, co może się jawić jako ostatnie bastiony nietkniętej natury i kultury. Paradoksalnie stają się oni 
mimo woli forpocztą ekspansji turystycznej. Ponadto istnieje kategoria turystów „hobbystycznych”, takich jak obserwatorzy ptaków czy wielorybów w ich naturalnym środowisku, entuzjaści żeglarstwa i rybactwa, łowcy tornad i burz, eksploratorzy jaskiń, ruin zamków czy budynków pofabrycznych. Rośnie również liczba turystów łączących doznania religijne i duchowe peregrynacji do miejsc kultu z innymi aktywnościami turystycznymi. Są też turyści „ekstremalni”, którzy szukają dreszczyku emocji i porcji niebezpieczeństwa w takich wyczynach, jak swobodna wspinaczka po eksponowanych skałach, base-jumping ${ }^{2}$, samotne wyprawy polarne lub loty w kosmos.

Wreszcie są i tacy, którzy uznają rozrywkę za zjawisko nazbyt płytkie i poszukują w podróży znacznie głębszych znaczeń, przyczyniając się do rozwoju nowych form turystyki, takich jak podróże edukacyjne, udział w wyprawach naukowych (na przykład w archeologicznych wykopaliskach), podejmowanie ochotniczej pracy przy różnorodnych projektach przyczyniających się do rozwoju społeczności wiejskich, służących ochronie przyrody czy pomocy humanitarnej (Cohen, 2011, s. 17-18).

Podsumowując, współczesna turystyka, choć mocno zglobalizowana (głównie $\mathrm{w}$ zakresie form zagospodarowania turystycznego, sposobów organizacji i udostępniania walorów turystycznych) z uwagi na powszechną dostępność wiedzy o świecie poszukuje nowych źródeł doznań i emocji, bazując na wąsko wykadrowanych wątkach, mogących przyciągnąc bardziej wymagających turystów. Coraz wyraźniej daje się zauważyć tematyczna dyspersja motywów podróży, sprzyjająca rozwojowi różnorakich form aktywności turystycznych. Głównym przejawem tych procesów jest wyodrębnianie się nowych form turystyki, które ogólnie można określić mianem turystyki tematycznej. Turyści zwiedzają bowiem muzea tematyczne, korzystają ze szlaków tematycznych, uprawiają wysoce specjalistyczne i kwalifikowane formy turystyki i rekreacji.

Wśród tematycznych aktywności turystycznych rozgrywających się często w specyficznych, specjalnie preparowanych i wyposażonych w tematyczne atrybuty obszarach wymienić można m.in. tanatoturystykę, turystykę filmową, turystykę industrialną, enoturystykę, turystykę biograficzną (tab. 2).

Większość form turystyki tematycznej zaliczana jest do pojemniejszej pojęciowo turystyki kulturowej. Turystyka kulturowa to aktywność podróżnicza, której główną motywacją jest poznawanie dziedzictwa kulturowego - materialnego i duchowego ludzkości - obiektów architektury i sztuki, wydarzeń kulturalnych, obyczajów, tradycji i sposobów życia grup ludzi lub regionów (Mikos v. Rohrscheidt, 2008, s. 52). Wyróżnia się trzy rodzaje turystyki kulturowej: turystykę kultury wysokiej (turystyka dziedzictwa kulturowego, muzealna, literacka, eventowa kultury wysokiej), turystykę edukacyjną (podróże edukacyjne, tematyczne, językowe, seminaryjne)

2 Sport ekstremalny, polegający na wykonywaniu skoków spadochronowych z obiektów, takich jak: wieżowce, mosty, maszty, urwiska górskie itp. 
Tabela 2. Wybrane formy turystyki tematycznej

\begin{tabular}{|c|c|}
\hline Forma turystyki & Cechy charakterystyczne \\
\hline Gastroturystyka & $\begin{array}{l}\text { odwiedzanie obszarów, gdzie zachowała się tradycyjna kuchnia, połączone } \\
\text { z degustacją potraw regionalnych i poznawaniem stylu życia i sposobów } \\
\text { wytwarzania produktów lokalnych }\end{array}$ \\
\hline Enoturystyka & $\begin{array}{l}\text { odmiana turystyki kulinarnej polegająca na odwiedzaniu rejonów upraw } \\
\text { winnej latorośli, zgłębianiu tajników winiarstwa połączonym ze zwiedzaniem } \\
\text { winnic, degustacji i zakupu lokalnych wyrobów }\end{array}$ \\
\hline Dark tourism & $\begin{array}{l}\text { ciemna, ponura turystyka, zjawisko zainteresowania śmiercią w aspekcie } \\
\text { miejsca tragedii ludzkiej i pamięci o niej, w wymiarze historycznym, eduka- } \\
\text { cyjnym i dziedzictwa kulturowego; obejmuje podróże do miejsc katastrof, } \\
\text { masowej śmierci, ludobójstwa i morderstw }\end{array}$ \\
\hline Tanatoturystyka & $\begin{array}{l}\text { rodzaj turystyki kulturowej, obejmuje podróże do miejsc publicznej śmierci } \\
\text { lub miejsc będących tego świadectwem, pomników upamiętniających zmar- } \\
\text { łych, do miejsc niezwiązanych bezpośrednio ze zdarzeniem, a prezentujących } \\
\text { dowody śmierci lub będących inscenizacją śmierci. Wyjazdy motywowane są } \\
\text { potrzebą rzeczywistego lub symbolicznego „kontaktu” ze śmiercią, zwłaszcza, } \\
\text { lecz niewyłącznie nagłą (brutalną) śmiercią }\end{array}$ \\
\hline Geoturystyka & $\begin{array}{l}\text { dział turystyki poznawczej, poznawanie obiektów i procesów geologicznych } \\
\text { i doznawanie w kontakcie z nimi wrażeń estetycznych }\end{array}$ \\
\hline $\begin{array}{l}\text { Turystyka fil- } \\
\text { mowa }\end{array}$ & $\begin{array}{l}\text { - podróże, których głównym celem jest zwiedzanie: muzeów biograficznych } \\
\text { słynnych gwiazd dużego i małego ekranu, miejsc ich urodzin, życia, pracy } \\
\text { i śmierci, oglądanie poświęconych im pomników, tablic pamiątkowych, odwie- } \\
\text { dzanie grobów aktorów, reżyserów, operatorów filmowych, udział w festiwa- } \\
\text { lach filmowych, spotkaniach z idolami itp. (turystyka biograficzna), } \\
\text { - wędrowanie w poszukiwaniu plenerów filmowych i telewizyjnych, czynny } \\
\text { i bierny udział w plenerowych inscenizacjach, spektaklach teatralnych czy } \\
\text { warsztatach filmowych, rodzinny wypoczynek w filmowych parkach rozrywki, } \\
\text { podróżowanie szlakami bohaterów filmowych itp. (turystyka fikcji filmowej) }\end{array}$ \\
\hline $\begin{array}{l}\text { Turystyka piel- } \\
\text { grzymkowa }\end{array}$ & turystyczna forma peregrynacji do miejsc kultu religijnego \\
\hline $\begin{array}{l}\text { Turystyka indu- } \\
\text { strialna }\end{array}$ & $\begin{array}{l}\text { forma turystyki realizowana w przestrzeniach industrialnych i postindustrial- } \\
\text { nych; inna nazwa to turystyka przemysłowa }\end{array}$ \\
\hline Slum tour & odwiedzanie dzielnic biedy w różnych regionach świata \\
\hline $\begin{array}{l}\text { Turystyka spor- } \\
\text { towa }\end{array}$ & $\begin{array}{l}\text { - podróże do miejsc, w których odbywają się duże imprezy sportowe (np. } \\
\text { igrzyska olimpijskie), } \\
\text { - odwiedziny sportowych aren (hal widowiskowo-sportowych, stadionów, } \\
\text { siedzib znanych klubów sportowych, skoczni narciarskich), } \\
\text { - podróże osób uprawiających sport amatorsko, związane z udziałem w im- } \\
\text { prezach sportowych, często wzbogacone elementami krajoznawczymi }\end{array}$ \\
\hline
\end{tabular}

Źródło: opracowanie własne na podstawie: Tanaś, 2006, s. 85-86; Słomka, Kicińska-Świderska, 2004, s. 5-6; http://www.academia.edu/6139599/Tanatoturystyka_przyk\%C5\%82ady_rozwi $\% \mathrm{C} 4 \% 85 \mathrm{za} \% \mathrm{C} 5 \% 84$ i_mo $\% \mathrm{C} 5 \%$ BCliwo $\% \mathrm{C} 5 \% 9 \mathrm{Bci}$ rozwoju_w_Polsce [dostęp 30.12.2014] na podstawie: Seaton, $1 \overline{99}$; Stasiak, 2009, s. 225; Kowalczyk, 2005, s. 186-191. 
oraz tzw. powszechną turystykę kulturową (turystyka miejska, kulturowa obszarów wiejskich, etniczna, militarna, obiektów przemysłowych i technicznych, żywej historii, kulturowo-przyrodnicza, egzotyczna, religijna i pielgrzymkowa, kulinarna, hobbystyczna).

Do młodszych form turystyki tematycznej, zdefiniowanych w ostatnich dwóch dekadach, zaliczyć można np. dark tourism i tanatoturystykę. Po raz pierwszy zostały one opisane w specjalnym numerze „International Journal of Heritage Studies" w 1996 r. przez Johna Lennona oraz Malcolma Foleya (Tanaś, 2006, s. 86).

Formą turystyki kreowaną przez Polską Organizację Turystyczną na jeden z krajowych produktów markowych i przeżywającą obecnie okres intensywnego rozwoju jest turystyka miejska. Przez lata wizyty w miastach ograniczały się do zwiedzania prawie wyłącznie dzielnic, w których skoncentrowane są najcenniejsze atrakcje (zabytki architektury, układy urbanistyczne) i usługi (uzdrowiskowe, kulturalne, gastronomiczne, rekreacyjne, biznesowe). Turyści stosunkowo niedawno zaczęli interesować się codziennym życiem mieszkańców miast, zwiedzając dzielnice mieszkalne 3 , biurowe (Le Defense, Paryż), etniczne (Chinatown, Chicago), mniejszości religijnych czy wreszcie tereny przemysłowe (Zagłębie Ruhry). Wychodząc w swych turystycznych przemieszczeniach poza utarte szlaki, decydują się na podjęcie ryzyka (do pewnego stopnia kontrolowanego) i wnikają do turpistycznych w swym charakterze dzielnic biedy w najuboższych zakątkach świata. Ta forma turystyki określana jest jako tzw. slum tour - turystyka slumsowa. Specyficzna atmosfera brazylijskich fawelli (Rio de Janeiro), hinduskich slumsów (Dharavi, Bombaj), afrykańskich bidonville (Kibera, Nairobi, Kenia), zdewastowanych i substandardowych dzielnic miast i osiedli zamieszkiwanych przez słowackich Romów (Koszyce) okazuje się być dla odwiedzających bardziej pociągająca, aniżeli uznane atrakcje turystyczne. Nawet $w$ tak niezwykłych i niebezpiecznych miejscach odwiedzający spotykają się ze swoistą narracją w przestrzeni, ze specjalnie dla nich przygotowywanymi inscenizacjami, a nawet bazą hotelową.

\section{Tematyzacja przestrzeni jako instrument rozwoju i zarządzania obszarami}

\subsection{Koncepcja procesów tematyzacji przestrzeni}

Na potrzeby silnie zdywersyfikowanych społeczeństw kreowane są niszowe przestrzenie nacechowane „wątkami przewodnimi”. Owe „tematy” mogą determinować atrybuty przestrzeni oraz sugerują, komu ona powinna służyć. Zauwa-

3 Przykładowo: do oferty przewodnickiej Krakowa weszły wizyty w „zwykłych” mieszkaniach w dzielnicy Nowa Huta, w których zachowały się meblościanki, nakrycia stołowe, dekoracje ścian pochodzące z okresu PRL (Polska Rzeczpospolita Ludowa) - autentyczne lub wykonywane współcześnie w typowych dla II połowy XX w. stylistyce i wzornictwie. 
żyć można, że fragmenty współczesnej przestrzeni geograficznej intensywniej niż kiedykolwiek wcześniej podlegają procesom tematyzacji, czyli ,świadomego i intencjonalnego nadawania im form architektonicznych nawiązujących do czasów minionych lub innych kręgów cywilizacyjnych, które może być powiązane z kreowaniem przeznaczonego dla masowego odbiorcy spektaklu" (Lorens, 2006, s. 11). Tematyzacja przestrzeni w takim ujęciu wiąże się z wytwarzaniem $\mathrm{i} /$ lub modernizacją przestrzeni (zazwyczaj publicznej), charakteryzującej się konkretnymi, specyficznymi formami urbanistycznymi i architektonicznymi, oferującej pewną „opowieść” mającą przyciągnąć i wzbudzić zainteresowanie widzów mieszkańców i odwiedzających.

Tematyzacja przestrzeni jest zjawiskiem, które rozwinęło się w USA i rozpowszechnia się obecnie na całym świecie; także w Polsce. Pojęcie to nawiązuje do amerykańskiego określenia theming, które pierwotnie odnosiło się do wesołych miasteczek i parków rozrywki wystylizowanych na baśniowe krainy. Dopiero w latach 90 . XX w. termin ten został zastosowany w odniesieniu do przekształceń przestrzeni miejskiej (Lorens, 2006, s. 12). Wydaje się jednak, że obserwowane obecnie w wielu płaszczyznach i obszarach procesy tematyzacji wykraczają poza wąskie ramy historyzacji przestrzeni pod względem urbanistycznym i architektonicznym oraz nadawania jej atrybutów zapożyczonych z innych regionów geograficznych.

Tematyzacja obejmuje różne przejawy dziedzictwa kulturowego ludzkości materialnego i duchowego - obiekty architektury i sztuki, wydarzenia kulturalne, obyczaje, tradycje i sposoby życia grup ludzi lub regionów i nie sprowadza się jedynie do fizycznych przekształceń przestrzeni. Rozwijając te rozważania zasadne wydaje się być stwierdzenie, że efektem procesów tematyzacji są wszelkie przestrzenie, które charakteryzują się nagromadzeniem połączonych wspólnym wątkiem specyficznych atrybutów i obiektów, wykreowanych celem pełnienia przezeń wyspecjalizowanych funkcji lub dla uzyskania efektu estetyzacji przestrzeni, współcześnie jak i w okresach historycznych. Taka interpretacja pojęcia pozwala przypisać tematyzacji przestrzeni zdecydowanie szersze znaczenie, a rodowód dłuższy nawet niż XVIII-wieczne „ogrody przyjemności” będące przodkiem amerykańskich parków rozrywki. Do przejawów zjawiska w ten sposób można również zaliczyć archetypiczne krajobrazy kulturowe o specyficznym charakterze, przykładowo te „od zawsze” kreowane przez wyznawców konkretnych religii w przestrzeniach sacrum.

Tematyzacja przestrzeni częściowo zbiega się znaczeniowo z pojęciem globalizacji, którą, zdaniem Giddensa (2002, s. 99) można rozumieć jako wyraz fundamentalnych aspektów „rozsuwania się czasu i przestrzeni”. Globalizacja i pozornie przeciwstawna jej glokalizacja dotyczą splotów społecznych wydarzeń i relacji „na odległość” z kontekstami lokalnymi. W procesach tematyzacji wprowadzanie elementów historyzujących do przestrzeni symbolicznie otwiera „wrota czasu", a zapożyczenia motywów z odległych pod względem fizycznym miejsc - „zakrzywiają przestrzeń”. 
W dobie globalnej konkurencji i kultury masowej, na tle mechanizmów kształtujących współczesne miasta - szczególnie przestrzenie publiczne - tematyzacja przestrzeni jawi się jako ważny instrument polityk przestrzennych. Pozwala na efektywny i ukierunkowany rozwój przestrzeni, co w praktyce oznacza powiązanie sposobów wykorzystania i urządzenia obszaru zgodnie z określonym tematem. Mergler, Pobłocki i Wudarski (2013, s. 4) są zdania, że najważniejszą, najkosztowniejszą - zarówno pod względem zysków (głównie partykularnych), jak i strat (głównie społecznych) - miejską grą w Polsce ostatnich kilkunastu lat jest gra o przestrzeń i gra przestrzenią. W czasach wzrostu wartości gruntów ważne jest więc kontrolowanie sposobów ich wykorzystania. Kontrolę w tej rywalizacji można zoptymalizować poprzez tematyzację, dopełniając przestrzeń silnym i wyrazistym elementem narracyjnym, pozwalającym wyeliminować lub stłumić niepożądane, kłócące się ze sobą obrazy, idee czy doznania, a nawet zlikwidować negatywne stereotypy przestrzenne.

Pod pojęciem „tematu” należy rozumieć świadome nawiązanie do określonego czasu, w tym do minionych okresów historycznych, do miejsc odległych w przestrzeni, a nawet do współczesnych cech realnie wyróżniających dany obszar bądź do wariacji ,na temat” jego właściwości. Wątkiem przewodnim może stać się przykładowo odcisk łapy prehistorycznego stwora, architektura starożytnego Egiptu, zabudowa współcześnie istniejącego starego galicyjskiego miasteczka, specyficzna specjalizacja produkcji rolnej, historia opowiedziana na kartach powieści lub w formie komiksów czy też wizja przyszłości wyabstrahowana z fantazji literackich lub naukowych prognoz. Odpowiednio dobrany „temat” stać się może katalizatorem rozwoju konkretnego obszaru, i co niewątpliwie ważne w czasach, gdy jednostki samorządu terytorialnego różnych szczebli coraz silniej konkurują między sobą, pozwala skuteczniej zabiegać o inwestorów, fundusze unijne i pieniądze turystów. Tematy pomagają sterować przestrzenią w taki sposób, że będzie przyciągała pożądaną publiczność, która zna przywoływane narracje i się z nimi utożsamia.

Największe doświadczenie w budowaniu przestrzeni tematycznych mają oczywiście korporacje medialne, zwłaszcza północnoamerykańskie. Specjalizują się one w narracjach i ikonach przekazujących te narracje w skrócie, posiadają również ogromne banki obrazów i opowieści. Przy kształtowaniu koncepcji rozwiązań przestrzennych i zarządzania obiektami tematycznymi w początkach $\mathrm{XX}$ w. skorzystano $\mathrm{z}$ testowanych wówczas, $\mathrm{w}$ trakcie światowych wystaw technicznych, zasad organizacji ekspozycji. Znaczącą rolę w rozwoju parków tematycznych odegrało też kino. Szybko podchwycono język i siłę oddziaływania ruchomego obrazu, za pomocą którego nauczono się artystycznie organizować świat percepcji człowieka, tworząc poczucie innej rzeczywistości (Александрова i Сединкина, 2011, s. 41-50). Symulacje realnych przestrzeni stały się tak perfekcyjne, że jak twierdzi Boudrillard (2005, s. 18-21) - Disneyland jest bardziej prawdziwy niż Stany Zjednoczone, które imituje w przesadnie egzaltowanej formie, w zminiaturyzowanej i komiksowej postaci. 
Tematyzacja przestrzeni to swoiste słowo „wytrych”, które wzbudza spore kontrowersje wśród urbanistów. W 2005 r. podczas debaty o odbudowie Nowego Orleanu po katastrofalnej powodzi, Daniel Liebeskind mówił, że należy pracować z historią, co nie znaczy imitować ją, symulować czy sprawić by stała się kiczem, ale sięgnąć do korzeni wielkiej kultury Nowego Orleanu i budować na jej podstawie. Jako najbardziej właściwy i naturalny „temat” wskazał jazz. Użycie wówczas pojęć theme i theeming wywołało falę krytyki i oskarżeń o powierzchowne, sztuczne, disneyowskie podejście do przestrzeni.

Tak zwana disneylandyzacja (lub disneyifikacja) przestrzeni, będąca dla niektórych badaczy najwyższym wcieleniem tematyzacji przestrzeni, wiąże się z zastąpieniem przestrzeni rzeczywistej przez jej odrealniony, bezpieczny odpowiednik, niekiedy pozbawiony zasadniczych cech pierwowzoru i złożony z form w rzeczywistości wspólnie ze sobą nigdzie niewystępujących. Przez wielu architektów i urbanistów efekt takiego działania krytykowany jest jako sztuczny, zamazujący i fałszujący prawdziwą tożsamość miejsca. Ale z drugiej strony, tematyzacja umożliwia skuteczne i wydajne rozwijanie konkurencyjności miejsc w różnych skalach: od placu czy centrum handlowego, po dzielnice czy całe miasta.

Na przykładach wielu amerykańskich miast i miasteczek doskonale widać, że narracje związane $\mathrm{z}$ daną przestrzenią są istotnym elementem lokalnej gospodarki i rozwoju. W miasteczku Salem w stanie Massachusetts, znanym z głośnych procesów czarownic w XVIII w., niemal cały przemysł turystyczny wykorzystuje motywy czarownic, wiedźm, okultyzmu i pochodnych zjawisk.

Procesy tematyzacji przestrzeni wprowadza się w życie, aby:

- poprawić jakość przestrzeni publicznej,

- zmodernizować elementy krajobrazu miejskiego,

- podnieść stopień komercjalizacji przestrzeni, kierując się głównie chęcią zainteresowania i pozyskania potencjalnego użytkownika (klienta),

- budować konkurencyjność miejsca (przestrzeni publicznej),

- uzyskać możliwość wydajnego, efektywnego budowania (lub przetwarzania) tożsamości lokalnej i regionalnej.

Tematyzacji przestrzeni publicznej, w tym przypadku kreowaniu pseudohistorycznego krajobrazu miasta, według Zuziak, towarzyszą zakrojone na znacznie szerszą skalę przemiany współczesnych struktur miejskich, w tym:

- komercjalizacja gospodarowania gruntami;

- wypieranie słabszych ekonomicznie podmiotów i typów programu miejskiego przez silniejsze;

- koncentracja wysiłku renowacyjnego (w odniesieniu do obiektów adaptowanych) do elewacji, często tylko do parteru;

- niekontrolowany rozwój rozmaitych nośników informacji w historycznej przestrzeni miast, w tym reklam (Zuziak, 1993, s. 88).

Ważnym problemem tematyzacji jest zachowanie autentyczności przestrzeni, przez którą rozumie się występowanie w przestrzeni form architektonicznych 
charakterystycznych dla okresu jej powstania. Problemem jest sformułowanie odpowiedzi na pytanie - Kiedy mamy do czynienia z tematyzacją przestrzeni, a kiedy po prostu z tworzeniem? (Lorens 2006, s. 15). Wydaje się, że granica między wyrażaniem $\mathrm{w}$ formach przestrzennych kultury, tożsamości i historii miejsca a tematyzacją bywa nieostra. Z punktu widzenia mieszkańców danego obszaru ważne jest kreowanie wartościowej, choćby i stylizowanej przestrzeni, która spełniałaby wymogi stawiane „dobrej przestrzeni”.

Zajmujący się opisywaniem zjawiska tematyzacji i skutków jej rozwoju dla tradycyjnej przestrzeni miejskiej Piotr Lorens stwierdza, że ma ona duże znaczenie w odniesieniu do miast polskich. Są one bowiem bardzo podatne na takie rozwiązania, z uwagi na następujące czynniki:

- gwałtowny rozwój motoryzacji,

- niedorozwój tradycyjnej przestrzeni publicznej (w znacznej części spowodowany zniszczeniami wojennymi oraz powojennymi procesami ułomnej urbanizacji),

- współczesną słabość samorządów miast (Lorens, 2006, s. 8).

Niekorzystnym zjawiskiem jest całkowite niekiedy oderwanie nowo projektowanych kompleksów od czasu i miejsca powstania pierwowzoru. Są to m.in. budowane na surowym korzeniu zespoły komercyjne, jak parki rozrywki czy centra handlowe, a także rozbudowywane struktury istniejących miast, jak np. kompleks Nowe Mikołajki. W tych przypadkach nie ma mowy o uzasadnieniach konserwatorskich czy chęci przywrócenia do stanu pierwotnego zniszczonych struktur miejskich - są to budowane od zera obiekty tematyczne, których jedyną funkcją jest przyciąganie klientów dysponujących większą gotówkę (Lorens 2006, s. 166-170).

\subsection{Charakterystyka obszarów tematycznych}

Przestrzenie tematyczne przyjmują bardzo zróżnicowane formy. Zasadniczo pełnią dwie podstawowe funkcje:

- codziennej przestrzeni publicznej,

- przestrzeni turystycznej.

Jednym z zabiegów wykorzystujących tematyzację przestrzeni jako instrument rozwoju obszarów i kreowania codziennej przestrzeni publicznej było od lat 50. XX w. budowanie na terenach dynamicznie rozrastających się przedmieść miast w USA tzw. shopping mall. Obiekty te, zwane również „regionalnymi centrami handlowymi", oferowały substytut przestrzeni publicznej śródmieścia. Była to sprywatyzowana wersja tradycyjnej amerykańskiej Main Street, czyli głównej ulicy handlowej miasta (Kunstler, 1994, s. 60). Starannie i bogato urządzone przestrzenie wspólne, wyposażone w ławki, gazony z kwiatami i inne elementy 
charakterystyczne dla tradycyjnej ulicy śródmiejskiej, bezpieczniejsze i czystsze niż oryginały, cieszyły się olbrzymią popularnością. Z czasem jednak te „maszyny do handlowania" (machines for trading) stały się monotonne i jednorodne. Wychodząc naprzeciw znudzeniu klientów ich powtarzalnością, deweloperzy, budując nowe obiekty lub modernizując już istniejące shopping malls, zaczęli nadawać im zróżnicowany i jednoznacznie określony tematyczny charakter. Sposób na odróżnienie od konkurencji stał się najkrótszą drogą do rozwoju procesów tematyzacji przestrzeni, w tym przypadku przestrzeni handlowych. Najprostszym rozwiązaniem było nawiązywanie do lokalnego charakteru zabudowy, sięgano również do stylu wiejskiego (rural style), a nawet wzorów europejskich (Lorens 2006, s. 60-61).

W specyficznych polskich warunkach tematyzacja przestrzeni często zazębia się z ochroną dziedzictwa kulturowego i procesami rewitalizacji, z kolei pojęcia te wiążą się działaniami rekonstrukcyjnymi i modernizacyjnymi tkanki miejskiej.

Jedną $\mathrm{z}$ form ochrony dziedzictwa w Polsce są parki kulturowe. Projekty realizowane na obszarach parków kulturowych wiążą się z jednej strony z petryfikowaniem struktur miejskich, $\mathrm{z}$ drugiej $-\mathrm{z}$ odtwarzaniem pewnych atrybutów architektonicznych, kreowaniem elementów narracji przestrzennej i odbudową społeczności lokalnych. Rekonstrukcja i estetyzacja przestrzeni nadają jej pewne cechy tematyzacji poprzez translokację budynków w konkretnym stylu i nagromadzenie elementów o określonych cechach np. małej architektury, detali architektonicznych. Obszar nie ulega klasycznej rewitalizacji, tj. nie następuje wyraźna zmiana funkcji, nie dochodzi do wymiany ludności etc. Ważne zmiany zachodzą natomiast w podejściu społeczeństwa do przestrzeni, dzięki czemu efekty modernizacyjne zostają wzmocnione wskutek działań samych mieszkańców. Wśród autochtonów narasta bowiem poczucie tożsamości z danym miejscem, stają się dumni ze swojego miejsca zamieszkania i własnymi siłami, nie korzystając ze środków zewnętrznych, starają się podejmować działania zmierzające do poprawy warunków życia.

Do form tematyzacji zaliczana jest retrowersja - rozumiana jako proces przywracania miastom ich struktury przy użyciu współczesnych środków architektonicznych, z wyraźnym nawiązaniem do historii, ale bez przesady, na miarę możliwości, głównie finansowych. Po II wojnie światowej w Polsce pojawiła się potrzeba odtwarzania średniowiecznych starówek miast zniszczonych wskutek działań wojennych. Nie stwarzano wówczas nawet pozorów, że odtwarza się stare kamienice. Zachowywano dawny układ ulic i pierzei oraz tradycyjną wysokość zabudowy, pozostałe elementy traktowane były z fantazją. Wprowadzano osobliwe kolory elewacji i dekory, historyczne piwnice zamieniano na garaże podziemne. Retrowersją objęto m.in. Stare Miasto w Elblągu, starówki - Starogardu Gdańskiego, Kołobrzegu, Głogowa, wyspy: Spichrzów i Ołowiankę w Gdańsku, szczecińskie Podzamcze (Sarzyński, 2012, s. 70-71). Trzebiatów, Słupsk czy Lębork stanowią kolejne, choć nieco mniej pozytywne przykłady zastosowania tej 
metody rekonstrukcji urbanistycznej i tematyzacji przestrzeni zarazem ${ }^{4}$. Za pozytywny skutek uznać należy przywrócenie miastom przestrzeni publicznej i atrakcyjnej substancji mieszkaniowej.

Retrowersja budzi mieszane uczucia. Za zrekonstruowanymi dość wiernie fasadami atrap dawnych budowli umieszcza się nowocześnie urządzone wnętrza. Miłośnicy historycznej architektury zżymają się i określają owe imitacje mianem wydmuszek. Trzeba jednak pamiętać, że za umiarkowane pieniądze odtwarza się w ten sposób, wizualnie, dawną tkankę miasta, a równocześnie tworzy funkcjonalne wnętrza na miarę XXI w. (Sarzyński, 2012, s. 72). Jednocześnie trudnym zadaniem jest określenie tożsamości obszaru. Nakłada się tu bowiem nie tylko oryginalny przekaz historii, ale także piętno wywarte na strukturze miejskiej przez określony sposób odbudowy.

Rewitalizacja mająca na celu unowocześnianie, modernizowanie i przemianę funkcjonalną zdegradowanej zabudowy ratuje ją przed całkowitym unicestwieniem. Bez rewitalizacji nie byłoby sukcesu łódzkiej Manufaktury, obecnie jednego z najchętniej odwiedzanych kompleksów handlowo-rozrywkowo-kulturalnych w Polsce, gdzie używając naturalnego wątku industrialnego, wykreowano jedną z najatrakcyjniejszych przestrzeni publicznych.

Przestrzenie tematyczne można dość swobodnie modyfikować. Dzięki temu mogą być też wielokrotnie „odkrywane” przez odwiedzających. Wystarczy zmiana sztafażu czy wprowadzenie nowego, uzupełniającego lub udoskonalonego wątku tematycznego i dany obszar wejść może w fazę odmłodzenia (rejuvenation), ujmując to w kategoriach butlerowskiego cyklu życia produktu turystycznego. Należy jednak operacje takie wykonywać niezwykle ostrożnie, tak by nie stracić zaufania wcześniej odwiedzających i zarazem dać sobie szansę na zainteresowanie nowych konsumentów. Istotne jest, w świetle delikatności materii walorów turystycznych, by nie przekształcać w stopniu drastycznym krajobrazu, a ich samych ewidentnie nie zubażać i nie ujednolicać. Według Cohena (2011, s. 22) charakterystyczne dla turystyki masowej jest zjawisko transformacji, polegające na dodatkowym ,uatrakcyjnianiu” atrakcji turystycznych. Nawet walory naturalne są poprawiane na potrzeby konsumpcji turystycznej.

R. J. Gangewere (2012, s. 4) definiuje theming jako zjawisko tworzenia miejsc, które odgrywają swojego rodzaju spektakl za pomocą zestawu pewnych cech i wartości, i jednocześnie stwierdza, że dzięki temu miejsca są wyróżnialne i atrakcyjne turystycznie. W klasyfikacji atrakcji turystycznej Sworbrooka wśród czterech grup atrakcji spotkamy kategorię: „miejsca zaprojektowane i zbudowane od podstaw jako atrakcje, przykładem tej grupy są parki rozrywki” (Kruczek, 2012, s. 29).

W literaturze przedmiotu funkcjonują różne podejścia do definiowania podstawowych terminów związanych z obszarami tematycznymi - park rozrywki (amu-

4 Współcześnie poligonem retrowersji może stać się niemal kompletnie unicestwiona starówka w Malborku. Wyzwaniem będzie zakamuflowanie postsocjalistycznego osiedla bloków wielorodzinnych, wybudowanych w miejscu dawnego Starego Miasta. 
sement park) i park tematyczny (theme park). Niektórzy badacze stawiają znak równości między tymi pojęciami (Kruczek, 2012, s. 30). W szerokim ujęciu pod pojęciem parku tematycznego rozumie się duży park wypoczynkowy z licznymi atrakcjami, restauracjami, sklepami, hotelami. Zaliczyć tu można różnie wyspecjalizowane parki wszelkich atrakcji rozrywkowych, a także delfinaria, oceanaria, ogrody zoologiczne wszystkich rodzajów, przeznaczone dla szerokiej publiczności, turystów, dzieci i dorosłych. Inne podejście opiera się na wydzieleniu szeregu cech separujących parki tematyczne od innych typów parków i od wszystkich innych obiektów typowo rekreacyjnych i rozrywkowych. Zgodnie z nim są to sztucznie stworzone poznawczo-rozrywkowe parki, których wszystkie struktury połączone są wspólnym tematem (Александрова, Сединкина, 2011, s. 9).

Zdaniem praktyków park tematyczny jest miejscem zawierającym jeden lub więcej obszarów tematycznych. Zwykle stanowi obszar zamknięty, o funkcji rekreacyjnej, z kontrolowanym dostępem. Na obszar parku składa się jedna lub kilka stref tematycznych oraz strefy uzupełniające - rekreacyjna i buforowa. Tereny rekreacyjne dostarczają odwiedzającym pożywki do zabawy, natomiast strefom buforowym nadaje się formę przestrzeni o funkcjach handlowych, ze sklepami, kawiarniami i stoiskami z pamiątkami. Kilka parków tematycznych połączonych obszarami rozrywkowymi i rekreacyjnymi zbliża się charakterem do parku rozrywki. Park rozrywki jest bardziej złożony niż prosty park miejski czy obszar rekreacyjny; utrzymany bywa w jednym bądź wielu klimatach (np. Amerykański Daleki Zachód, Piraci z Karaibów). Alternatywnym określeniem może być tematyczny park rozrywki (Rzeńca, 2012, s. 408).

Parki rozrywki choć generalnie pojawiły się w epoce industrialnej, wpisując się w charakterystyczne dla turystyki tego okresu cechy, jak ,zmiana” (change), „komercjalizacja” (commercialization) i ,utowarowienie” (commodification), to ich ewoluujące formy wprowadziły turystykę w epokę postindustrialną, w której istotną rangę uzyskały: „znaczenie” (menning), „nowość” (nevelty) i „tożsamość” (identity) (Hughes, 2003, s. 64-66). Są więc te obiekty pomostem w czasie pomiędzy formami turystyki opisanymi paradygmatem $3 \mathrm{~S}$, odnoszącymi się do zjawisk turystycznych dominujących w II połowie XX w., a wciąż dojrzewającym paradygmatem $3 \mathrm{E}$.

Współczesne parki rozrywki przyciągają w skali świata ogromną liczbę turystów, z których większość wybiera obiekty typu disneyowskiego ${ }^{5}$. Na całym świecie bazują one na podobnej organizacji przestrzeni, motywach i walorach turystycznych, stąd trudno oceniać ich realną wartość kulturową, której miernikiem nie może być jedynie frekwencja ${ }^{6}$. Prawdopodobnie dopiero w przyszłości badacze, patrząc z perspektywy lat na parki rozrywki i zbliżone do nich charakterem obiekty, będą w stanie ustosunkować się do ich wartości i wpływu na społeczeństwo.

\footnotetext{
5 Pierwszy Disneyland powstał w 1955 r. w Anaheim (Kalifornia, USA).

${ }^{6} \mathrm{~W} 2010 \mathrm{r}$. parki rozrywki odwiedziło ponad $320 \mathrm{mln}$ gości (Theme index, 2011).
} 
Geografowie wskazują parki tematyczne jako dynamiczny produkt turystyczny kreowany przez różne grupy inicjatywne - prywatne firmy, organizacje społeczne, jednostki samorządu terytorialnego poszukujące nowych dróg rozwoju i sposobów rozwiązywania lokalnych problemów społecznych i gospodarczych. Urbaniści widzą w nich jeden z czynników modyfikujących przestrzenie publiczne (Lorens 2006, s. 7), socjologowie specyficzną przestrzeń konsumpcji (Miles 2010, s. 142-147), ekonomiści kultury zaś upatrują w nich dóbr, które - tak jak wszelkie inne produkty i usługi produkowane w ramach systemu gospodarczego - mogą być konsumowane (Throsby 2010, s. 25-26).

Obiekty tematyczne konstruuje się w oparciu o konkretny „temat”. Zazwyczaj jest to motyw baśniowy, rzeczywista osoba lub wydarzenie, ciekawy zawód, zjawiska przyrodnicze itd. Wśród eksploatowanych tematów wyróżnić należy: skamieniałości dinozaurów (np. JuraPark, Bałtów), życie ludzi w epokach historycznych (Centrum Słowian i Wikingów, „Wolin-Jomsborg-Wineta”), świat w miniaturze (Park Miniatur, Ogrodzieniec), bohaterowie baśni, legend i bajek (Europejskie Centrum Bajki im. Koziołka Matołka, Pacanów), klimat tropików (Tropical Islands, Berlin) (Rzeńca, 2012, s. 197).

W Polsce tematyzacja przestrzeni publicznej miast nie znalazła tak pożywnego gruntu, jak w USA. Jednocześnie dynamika zjawiska rozwoju parków tematycznych w Polsce jest olbrzymia (rys. 2). Obiekty mają zdecydowanie mniejsze rozmiary, są słabiej wyposażone w atrakcje zarówno tematyczne, jak i rozrywkowe (Rzeńca, 2014, s. 164). Prawie 3/4 polskich obiektów tematycznych (71\%) powstało na terenach wiejskich, natomiast $\mathrm{w}$ miastach średniej wielkości (2050 tys. mieszkańców) i miastach dużych (powyżej 50 tys. mieszkańców) było ich odpowiednio $10 \%$ i $19 \%$ ?

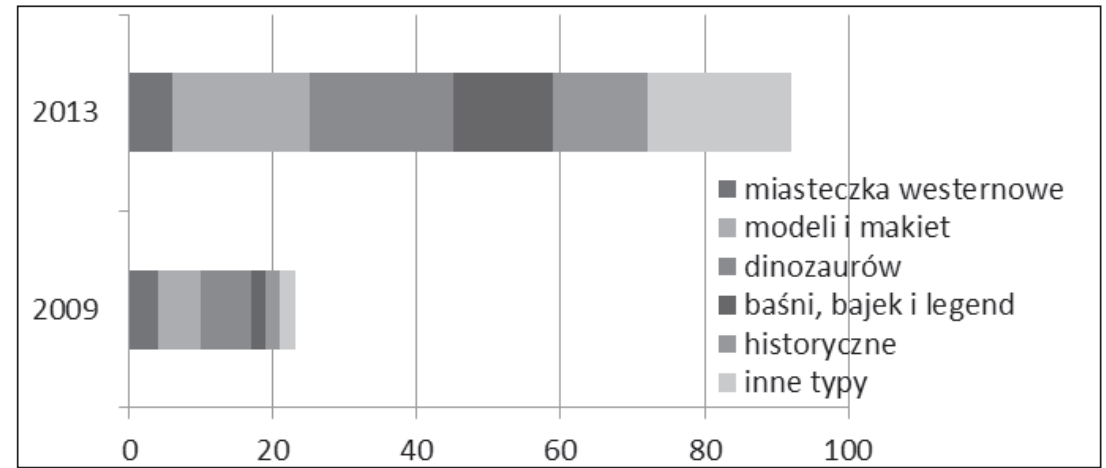

Rysunek 2. Dynamika rozwoju ekspozycji tematycznych w Polsce

Źródło: Rzeńca, 2014, s. 162

${ }^{7}$ Obliczenia na podstawie badań własnych i danych zawartych w pracy J. Poczobut (2012). 


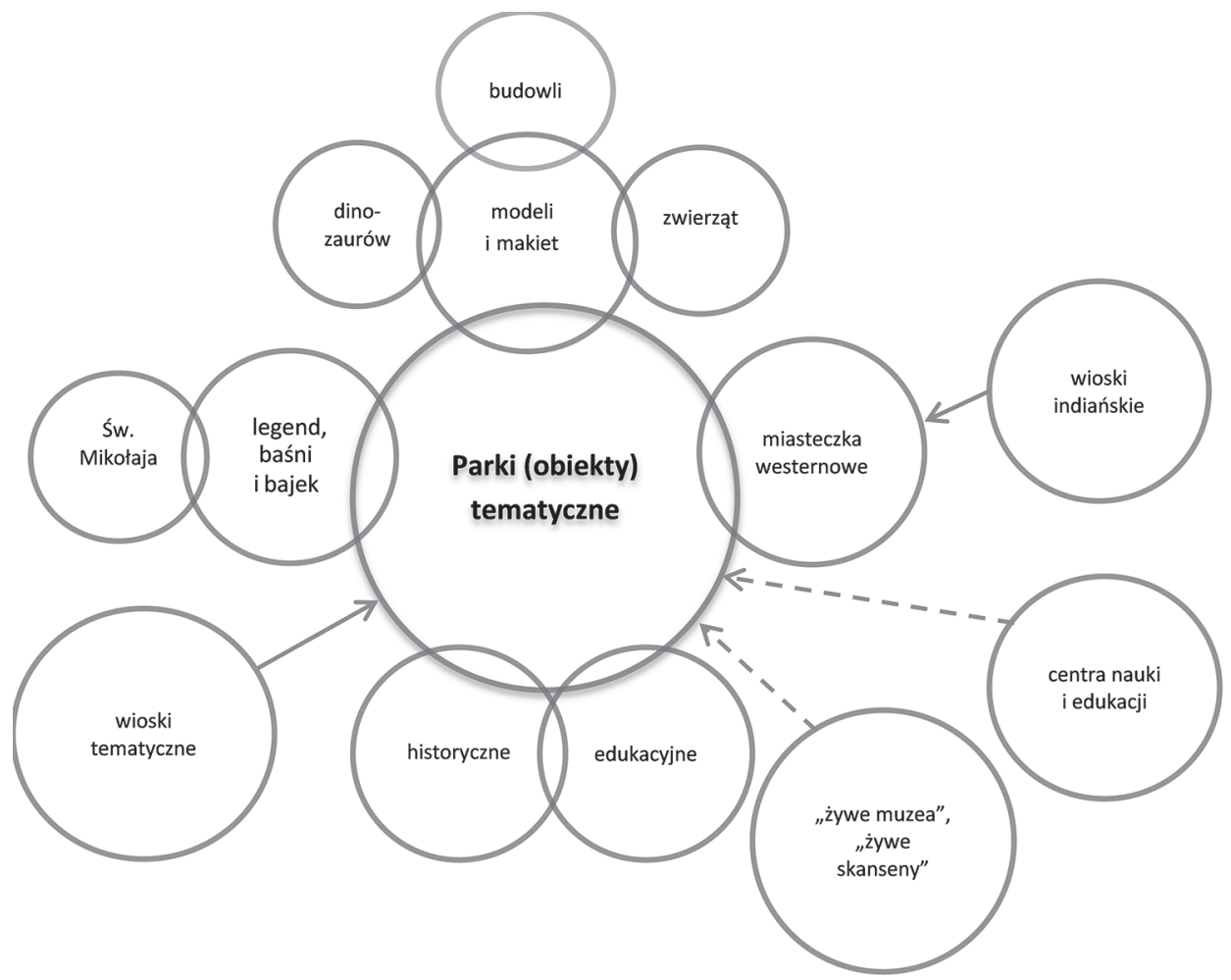

Rysunek 3. Zróżnicowanie form obiektów tematycznych w Polsce

\section{Źródło: opracowanie własne}

W 2009 r. istniały 24 ekspozycje tematyczne, a w cztery lata później odnotowano już ich ponad 90, zlokalizowanych w 70 obiektach tematycznych, w każdym z województw Polski. W pięciu miejscowościach usytuowane są po dwa parki tematyczne (tab. 3). Doliczając wioski tematyczne (około 70-80 lokalizacji) i wioski indiańskie (ponad 30 lokalizacji) łączna liczba obiektów w kraju przekraczać może nawet 200. Mimo swej krótkiej historii parki tematyczne w Polsce są już bardzo zróżnicowane (rys. 3).

Wśród ekspozycji dominują parki modeli i makiet (55\%) - miniaturowych budowli (parki miniatur), dinozaurów, owadów i innych zwierząt. Największy udział mają parki miniatur (20 obiektów) i parki dinozaurów (19 obiektów), nieco im ustępują parki bajek, baśni i legend (14 obiektów) oraz parki historyczne (13 obiektów). Wielkość powierzchni waha się od 0,5 do 50 ha. Wśród najmniejszych przodują parki miniatur (np. Mikrokosmos Ujazd); największe reprezentowane są przez parki jurajskie (Jurapark Krasiejów; JuraPark Bałtów). 
Tabela 3. Ekspozycje i obiekty tematyczne w Polsce w 2013 r.

\begin{tabular}{|c|c|c|c|c|}
\hline \multirow[b]{2}{*}{ Województwo } & \multirow[b]{2}{*}{$\begin{array}{c}\text { Ilość } \\
\text { lokalizacji }\end{array}$} & \multicolumn{2}{|c|}{ Obiekty tematyczne } & \multirow[b]{2}{*}{$\begin{array}{c}\text { Ilość } \\
\text { ekspozycji } \\
\text { tematycznych }\end{array}$} \\
\hline & & ogółem & $\begin{array}{c}\text { obiekty } \\
\text { wielowątkowe/ } \\
\text { multitematyczne }\end{array}$ & \\
\hline Dolnośląskie & 6 & 8 & & 8 \\
\hline Kujawsko-pomorskie & 5 & 5 & 2 & 10 \\
\hline Lubelskie & 2 & 2 & & 2 \\
\hline Lubuskie & 1 & 1 & & 1 \\
\hline Łódzkie & 2 & 2 & 2 & 4 \\
\hline Małopolskie & 3 & 4 & 2 & 10 \\
\hline Mazowieckie & 2 & 2 & 1 & 3 \\
\hline Opolskie & 2 & 2 & & 2 \\
\hline Podkarpackie & 5 & 6 & & 6 \\
\hline Podlaskie & 2 & 2 & & 2 \\
\hline Pomorskie & 10 & 10 & 1 & 11 \\
\hline Śląskie & 9 & 9 & 3 & 12 \\
\hline Świętokrzyskie & 3 & 4 & 1 & 5 \\
\hline Warmińsko-mazurskie & 2 & 2 & 1 & 4 \\
\hline Wielkopolskie & 5 & 5 & 1 & 6 \\
\hline Zachodniopomorskie & 6 & 6 & & 6 \\
\hline Ogółem & 65 & 70 & 14 & 92 \\
\hline
\end{tabular}

Źródło: opracowanie własne.

Właścicielami obiektów są osoby prywatne, stowarzyszenia i fundacje, spółdzielnie oraz jednostki samorządu terytorialnego, wspomagane w swych działaniach przez Lokalne Grupy Działania oraz Grupy Odnowy Wsi. Niektóre współcześnie kształtowane parki tematyczne zaczynają przybierać formy hybryd, co przejawia się aglomerowaniem ekspozycji o różnych wątkach przewodnich. Istnieje 14 takich aglomeratów ( $20 \%$ obiektów tematycznych), powiązanych ze sobą bliskim sąsiedztwem, czasami także połączonych na płaszczyźnie instytucjonalno-administracyjnej, zazwyczaj poprzez wspólnego właściciela lub zarządzającą instytucję. Dodawanie nowych, coraz bardziej ekscytujących i zaawansowanych technicznie atrakcji pozwala podtrzymać frekwencję (Rzeńca, 2014, s. 162-164). Takie zadanie ma również spełniać wyjście z tematyzacją w przestrzeń otaczającą obiekty (tab. 4).

Konieczność konkurowania o masowego odbiorcę rodzi silną konwergencję cech muzeów specjalistycznych i centrów nauki (np. Muzeum Powstania 
Warszawskiego, Centrum Nauki „Kopernik”, Warszawa) do cech parków tematycznych. Istotą ich rywalizacji staje się umiejętność story telling - opowiadania historii czy prowadzenia narracji, w tym przypadku przy zastosowaniu narzędzi o charakterze przestrzennym (Rzeńca, 2012, s. 408). Pierwiastki popularno-naukowe i edukacyjne zawarte w ofercie obiektów tematycznych dają możliwość poszerzania posiadanych wiadomości i wiedzy. Pobudza to wzrost znaczenia turystyki kulturowej i poznawczej, czego doskonałym przykładem są niezwykłe kariery wspomnianych powyżej obiektów, które ze swymi interaktywnymi ekspozycjami stały się wyznacznikiem kierunków rozwoju „nowej turystyki”.

Tabela 4. Charakterystyka wybranych obiektów tematycznych w Polsce

\begin{tabular}{|c|c|c|}
\hline Nazwa obiektu & Typ obiektu & Charakterystyka obiektu \\
\hline JuraPark Bałtów & $\begin{array}{l}\text { park tematyczny - } \\
\text { jurajski (dinozaurów), } \\
\text { ewoluujący w kierunku } \\
\text { parku rozrywki }\end{array}$ & $\begin{array}{l}\text { - inicjatywa Stowarzyszenia Delta i Stowarzyszenia } \\
\text { na Rzecz Rozwoju Gminy Bałtów „Bałt” } \\
\text { - wątek pierwotny inicjatywy - autentyczne tropy } \\
\text { dinozaurów } \\
\text { - wpływ na bezpośrednie otoczenie - bardzo silny, } \\
\text { wyraźny spadek liczby bezrobotnych; liczne kolejne } \\
\text { inwestycje, m.in.: stacja narciarska, Zwierzyniec } \\
\text { Bałtowski, rollercaster, spływ tratwami, Wioska św. } \\
\text { Mikołaja, park rozrywki, prehistoryczne oceanarium }\end{array}$ \\
\hline $\begin{array}{l}\text { Europejskie } \\
\text { Centrum Bajki } \\
\text { im. Koziołka } \\
\text { Matołka, Paca- } \\
\text { nów }\end{array}$ & $\begin{array}{l}\text { park tematyczny } \\
\text { - legend, baśni i bajek }\end{array}$ & $\begin{array}{l}\text { - inicjatywa władz samorządowych } \\
\text { - wątek pierwotny inicjatywy - fikcyjna postać } \\
\text { bajkowa stworzona przez K. Makuszyńskiego } \\
\text { - wpływ na bezpośrednie otoczenie - silny, rozwój } \\
\text { bazy noclegowej, liczne obiekty usługowe, obiekty } \\
\text { małej architektury i detale dekoracyjne nawiązujące } \\
\text { do postaci Koziołka Matołka (nazwy obiektów, } \\
\text { kolorystyka elementów, wizerunki postaci - pomni- } \\
\text { ki, rzeźby, malowidła); inicjatywy uzupełniające - } \\
\text { questing, gry terenowe }\end{array}$ \\
\hline $\begin{array}{l}\text { Mikrokosmos } \\
\text { - Park Edukacyj- } \\
\text { no-Rozrywkowy, } \\
\text { Ujazd }\end{array}$ & $\begin{array}{l}\text { park tematyczny } \\
\text { - modeli i makiet } \\
\text { zwierząt }\end{array}$ & $\begin{array}{l}\text { - inicjatywa prywatna } \\
\text { - wątek pierwotny inicjatywy - zainteresowania, } \\
\text { hobby i wykształcenie inicjatorów założenia obiektu } \\
\text { - wpływ na bezpośrednie otoczenie - niewielki, } \\
\text { przestrzeń w pobliżu obiektu w znikomym stopniu } \\
\text { uległa procesom tematyzacji; w planach na rok } 2015 \\
\text { jest powstanie nowej ekspozycji w innym miejscu, } \\
\text { położonym w pobliżu dotychczasowego }\end{array}$ \\
\hline
\end{tabular}

Źródło: opracowanie własne. 
Tematyzacja prowadzi do powstania dwóch zasadniczych typów przestrzeni. Pierwszym z nich jest przestrzeń otwarta, publiczna, o funkcjach rozrywkowo-poznawczych lub handlowych, swobodnie penetrowana przez odwiedzających. Do drugiego typu zaliczyć należy przestrzenie prywatne (niepubliczne, często udające przestrzeń publiczną), skomercjalizowane, dostępne za opłatą. $\mathrm{W}$ typie tym mieszczą się w większości parki tematyczne i parki rozrywki.

Część przestrzeni tematycznych przyjmuje formę przestrzeni tymczasowych (przestrzeni wspólnotowej, egzystencjonalnej). Cechuje je nietrwałość. Mogą to być instalacje tymczasowe łączące elementy z pogranicza sztuki i architektury, a nawet obiekty tymczasowe chociażby w postaci straganów wystawianych podczas parafialnych odpustów. Innymi formami mogą być ogrody tymczasowe ${ }^{8}$ (ang. temporary garden, fr. jardin temporaire), zakładające używanie komponentów roślinnych. Część z nich może oddziaływać na przestrzeń, w której się znajdują (Herman, 2011, s. 13), tworząc pewną opowieść, która przyciąga uwagę i zainteresowanie, współtworząc przestrzeń kolektywnąa . Herman (2011, s. 22) stwierdza: „Ogrody są rzeczywiście przeróżne. Są częścią naszych domów, pięknymi miejscami, miejscami dla roślin, wypoczynku i rozrywki”. Dalsza część opisu bardziej uwypukla cechy wspólne ogrodów z cechami przestrzeni tematycznych: „Ogrody mogą przywoływać inne miejsca, mogą symbolicznie ukazywać światopogląd, kosmos, status społeczny. Ogrody są uporządkowane [...]”. Ogrody są zatem „wypowiedziami”, dzięki którym prowadzić można narrację w przestrzeni, ukazując, jak to było wcześniej wspomniane, „odległe lub nieokreślone miejsca”, jak i ucieleśniać pewne idee. Posiłkując się definicją Hermana (2011, s. 28), przyjąć można, że forma ogrodu wyraża ,powiązane praktyczne, społeczne, duchowe lub estetyczne przyczyny jego istnienia". Ogrody - warzywne, użytkowe - tworzone w czasie wojen, są wyrażeniem niezbędnej, podstawowej potrzeby; mogą też ukazywać przepych, status społeczny. Herman opracował typologię ogrodów tymczasowych, wyróżniając:

- ogrody nomadyczne (ogrody bezdomnych i ogrody przy przyczepach kempingowych ${ }^{10}$ ),

- tymczasowe uliczne dekoracje kwiatowe,

- ołtarze i dywany kwietne,

8 Termin „ogród tymczasowy” nie doczekał się pogłębionego opracowania i zdefiniowania dla potrzeb nauki i praktyki zawodowej w Polsce (Herman, 2011, s. 7). Pierwszą potrzebę zdefiniowania tego pojęcia zauważyła Karolina Skonieczna, pisząc, że „temat jest nowatorski i niezbadany” (Skonieczna, 2007, s. 4-5).

9 Autorski termin sformułowany przez hiszpańskiego architekta Sola-Moralesa.

10 Niektóre kempingi w Niemczech posiadają sektory przeznaczone wyłącznie dla przyczep kempingowych. Służą one jako domy wakacyjne, letniskowe, a otoczenie ich jest kompleksowo zagospodarowane, np. wewnętrzne uliczki mają nadane nazwy, a niemal każda przyczepa otoczona jest miniaturowym ogródkiem o tymczasowym charakterze. 
- roślinne dekoracje przy miejscach pamięci,

- stragany z materiałem roślinnym (stragany kwiatowe, stragany z choinkami),

- ogródki gastronomiczne,

- ogrody pokazowe na festiwalach ogrodowych,

- tymczasowe interwencje artystyczne z komponentem roślinnym,

- „zielone” reklamy zewnętrzne.

\subsection{Typologie przestrzeni tematycznych}

Piotr Lorens (2006, s. 94-95), autor wielu publikacji podnoszących problematykę tematyzacji, wskazał szereg kryteriów i cechy określające przestrzenie tematyzowane (tab. 5).

Tabela 5. Charakterystyka kryteriów wykorzystywanych w typologii przestrzeni tematycznych

\begin{tabular}{|l|l|}
\hline \multicolumn{1}{|c|}{ Kryterium } & \multicolumn{1}{c|}{ Cechy szczególne } \\
\hline Rodzaj użytego tematu & $\begin{array}{l}\text { - specyfika historii; odległość wzorca w czasie i przestrzeni } \\
\text { - wykorzystanie motywów fantastycznych, symulacje nieist- } \\
\text { niejących światów } \\
\text { - naśladownictwo tkanki miejskiej o lokalnym, tradycyjnym } \\
\text { charakterze }\end{array}$ \\
\hline $\begin{array}{l}\text { Wielkość tematyzowanego } \\
\text { zespołu }\end{array}$ & $\begin{array}{l}\text { - stopień rozwinięcia przestrzennego zespołu, np. jeden } \\
\text { obiekt, zespół budynków, osiedle lub dzielnica mieszkaniowa, } \\
\text { samodzielne założenie urbanistyczne (małe miasteczko) }\end{array}$ \\
\hline $\begin{array}{l}\text { Relacje pomiędzy tematem } \\
\text { a programem funkcjonalnym }\end{array}$ & $\begin{array}{l}\text { - tematyczność wspierająca lub uzupełniająca funkcje obiek- } \\
\text { tu, przestrzeni } \\
\text { - tematyczność determinująca funkcje obiektu, przestrzeni }\end{array}$ \\
\hline $\begin{array}{l}\text { Przewidywane funkcje i sposoby } \\
\text { wykorzystania projektowanych } \\
\text { zespołów }\end{array}$ & $\begin{array}{l}\text { funkcje wiodące obszarów tematycznych } \\
\text { - handlowa } \\
\text { - rozrywkowa } \\
\text { - mieszkaniowa }\end{array}$ \\
\hline $\begin{array}{l}\text { Relacje między konceptami: ar- } \\
\text { chitektonicznym i tematycznym }\end{array}$ & $\begin{array}{l}\text { - tematyzacja pierwotna, wyprzedzająca powstanie obiektu; } \\
\text { tematyzacja zintegrowana } \\
\text { - tematyzacja opóźniona względem powstania obiektu; tema- } \\
\text { tyzacja wtórna }\end{array}$ \\
\hline
\end{tabular}

Źródło: opracowanie własne, częściowo na podstawie: Lorens, 2006.

Na podstawie kombinacji kryteriów i cech Lorens zaproponował przypisanie przestrzeni tematycznych do trzech podgrup (rys. 4). 


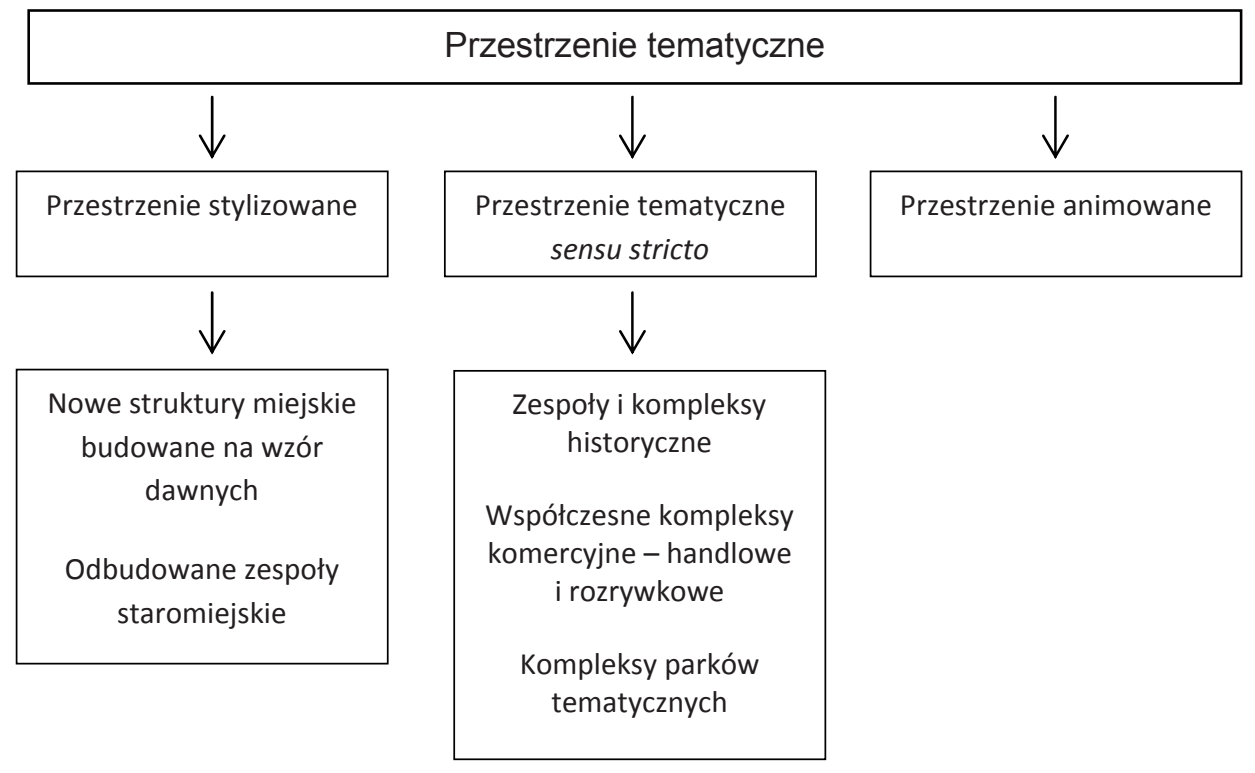

Rysunek 4. Typy przestrzeni tematycznych

Źródło: opracowanie na podstawie: Lorens, 2006

Przestrzenie tematyczne sensu stricto odnoszą się zarówno do świadomego nadawania przestrzeni form kulturowo lub czasowo obcych okresowi ich powstania, jak i powiązane są kreacją spektaklu (miejskiego) oraz prowadzeniem narracji mającej zainteresować widza. $Z$ kolei w przestrzeniach stylizowanych główny nacisk kładzie się na elementy architektoniczne zapożyczane z różnych okresów historycznych i przestrzeni geograficznych. O charakterze tematyzacji stanowią w tym ostatnim przypadku elementy materialne. Przestrzenie pozbawione natomiast prób stylizacji architektonicznej, kreowane przy użyciu współczesnego języka form architektonicznych, ale jednocześnie spełniające kryterium kreowania przeznaczonego dla masowego odbiorcy spektaklu miejskiego nazywane są przestrzeniami animowanymi (Lorens, 2006, s. 12).

Jedną z głównych funkcji przestrzeni tematycznych jest funkcja rozrywkowa. Anna Franta (2004, s. 65) wyróżnia szereg przykładów „przestrzeni rozrywki”:

- miasta rozrywki (np. Las Vegas będące żywym organizmem jest przestrzenią rozrywki, której doskonałości podporządkowana jest intencjonalnie tworzona architektura złudzeń);

- miasta falsyfikaty - naśladujące miasta (np. ghost towns - „wymarłe” miasta górnicze, gdzie poziom imitacji, choć wykorzystuje się zakonserwowaną, autentyczną tkankę miejską, jest bardzo wysoki, a jednocześnie gdzie wrażenie uczestnictwa $\mathrm{w}$ handlowym przedsięwzięciu (realnym życiu miasta) z racji na- 
gromadzenia środków iluzji przerasta poczucie fikcyjności przedsięwzięcia lub teatralności sytuacji;

- „kondensaty” miast prawdziwych, np. imitacja Nowego Orleanu wykonana na potrzeby przemysłu filmowego w Uniwersal Studios, w Orlando, na Florydzie, która z racji perfekcji środków technicznych wykorzystanych do wykreowania iluzji procesów miejskich i imitacji substancji miasta wyprzedza ,jakością" kondensatu rozwleczony w przestrzeni, niekomercyjny, aczkolwiek realny pierwowzór;

- architektura statków wycieczkowych (np. wycieczkowa flota karaibska).

\section{Park Kulturowy Miasto Tkaczy w Zgierzu - case study przestrzeni tematycznej}

Zgierz to miasto w centralnej Polsce, którego rozwój od początku XIX w. do niemal końca XX w. związany był głównie z przemysłem włókienniczym, podobnie zresztą jak większości miast aglomeracji łódzkiej, co było skutkiem decyzji władz o lokalizacji osad rękodzielniczych i tkackich w tej części Królestwa Polskiego. Dzisiejszy układ przestrzenny centrum miasta jest w dużej mierze oparty na układzie ulic tzw. Nowej Osady utworzonym w XIX w. Na terenie położonym w centralnej części Zgierza, gdzie kiedyś mieściła się jedna z osad włókienniczych, przy dzisiejszych ulicach: Rembowskiego, Dąbrowskiego, Narutowicza, Dubois stoi 30 drewnianych domów tkaczy z XIX w. Jest to wyjątkowo wartościowy kulturowo kompleks urbanistyczno-przestrzenny - tak dobrze zachowany i oryginalny układ ulic i domów jest jednym z niewielu z czasów osadnictwa sukienniczego i tkackiego z XIX w. w Polsce, a nawet w skali kontynentu. Z tego powodu narodził się pomysł ochrony ważnego dla kultury europejskiej i życia codziennego miasta terenu $\mathrm{w}$ formie parku kulturowego, którego zadaniem stała się ochrona zabytkowej architektury z XIX w.

Miasto Zgierz w 2008 r. przystąpiło do konkursu z pomysłem projektu rewitalizacji kompleksu dawnych, drewnianych domów tkaczy. Obiekty te potrzebowały natychmiastowej renowacji ze względu na zły stan większości z nich. Projekt Parku Kulturowego Miasto Tkaczy zyskał aprobatę mieszkańców i organizatora konkursu - Norwegii. Zgierz jako jedno z nielicznych miast otrzymało środki finansowe w ramach Mechanizmu Norweskiego oraz Europejskiego Obszaru Gospodarczego na realizację planowanej inwestycji.

Dużą część środków finansowych z budżetu oraz dofinansowania Unii Europejskiej i Funduszu Norweskiego przeznaczono na realizację celu w zakresie rewitalizacji zabytkowej części miasta. Dzięki funduszom stało się możliwe ukończenie kolejnego etapu przebudowy Placu Kilińskiego oraz odtworzenie Miasta Tkaczy. Ze względu na wyjątkowość miejsca, miasto przywiązuje dużą uwagę do zachowania w jak najlepszym stanie sieci ulic oraz elementów powiązanych 
w postaci zabudowy i obiektów małej architektury. Bardzo pomocnymi narzędziami okazały się rekonstrukcje, translokacje oraz remonty poszczególnych domów. W kolejnych latach są zaplanowane kolejne rekonstrukcje wyglądu ulic i domów w granicach parku kulturowego.

Obecnie Park Kulturowy Miasto Tkaczy boryka się m.in. z problemami finansowymi i organizacyjnymi, co w znaczący sposób wpływa na jakość przyjętych $\mathrm{w}$ projekcie przedsięwzięć. Barierą $\mathrm{w}$ funkcjonowaniu parku jest nie tylko brak funduszy w budżecie miasta. Nie stworzono również stanowiska pełnomocnika ds. parku kulturowego, który w znaczący sposób mógłby się przyczynić do rozwoju tego miejsca. Taka sytuacja znacząco utrudnia pracę organów, które miały za zadanie aktywizować społeczeństwo. Zadania takie „przejął” tzw. Dom Turysty, którego pracownicy we własnym zakresie oraz w ramach ograniczonych możliwości finansowych prowadzą działalność na rzecz podniesienia aktywności i wiedzy mieszkańców w zakresie turystyki i edukacji. Na te szkolenia i kursy fundusze pozyskiwane są między innymi ze sprzedaży tradycyjnych wyrobów własnych. W budynku Domu Turysty miała być zorganizowana także galeria sztuki, która do końca nie spełniała wymogów zawartych w umowie. Muzeum Miejsca ma przybliżać ludziom zarówno idee rewitalizacji i pokazywać projekt rewitalizacyjny, jak również organizować pobyty dla studentów z Norwegii celem zapoznania ich z tematem rewitalizacji, translokacji i historią miasta Zgierza. Do tej pory nie zostało zorganizowane ani jedno spotkanie z powodu braku wskazania osoby odpowiedzialnej za tego typu przedsięwzięcia.

Pozytywnym aspektem projektu stały się działania na rzecz integracji postaw mieszkańców z procesami rewitalizacji. Z czasem mieszkańcy Zgierza zaangażowali się w tworzenie ekspozycji, pożyczając rodzinne, zabytkowe przedmioty. Wspólnie zaczęto ustalać tematy i kierunki działalności oraz spotkań. W 2012 r. w imprezach i wydarzeniach rekreacyjnych organizowanych przez Dom Turysty uczestniczyło łącznie 2405 osób, które miały możliwość obejrzenia projekcji multimedialnej na temat historii przemysłu włókienniczego, a także udziału w warsztatach rękodzielniczych: kowalstwa, hafciarstwa i tkactwa. W marcu 2012 r. nastąpiło uroczyste otwarcie motelu i przebudowanej restauracji działającej aktualnie pod nazwą „Biedermeier”, które prowadzi Stowarzyszenie „Wsparcie społeczne JA-TY-MY”. Władze miasta nawiązały także porozumienie z uczelniami wyższymi, które w znaczący sposób miałyby pomóc w działalności parku kulturowego.

\section{Podsumowanie}

Niepodważalne jest znaczenie turystyki dla gospodarek regionów i miast. Istnieją obszary i ośrodki, których codzienny byt uzależniony jest w bardzo dużym stopniu od odwiedzających, a organizacja i funkcje podporządkowane są ich ob- 
słudze. Przy współczesnym umasowieniu i spowszednieniu tradycyjnych atrakcji istnieje silnie artykułowana potrzeba kreowania nowych przestrzeni, wśród których coraz częściej pojawiają się przestrzenie (lub szlaki) tematyczne. Przestrzenie te, z racji nagromadzenia wyrazistych i konkretnych atrybutów, stają się interesujące zarówno dla odwiedzających, jak i mieszkańców. Wymuszają rozwój specyficznych form zagospodarowania przestrzeni i wchodzą w swoistą interakcję z systemem zarządzania miastem i regionem.

\section{Bibliografia}

Александрова А. Ю., Сединкина О. Н. (2011), Тематические парки мира, КНОРУС, Москва. Baudrillard J. (2005), Symulacje i symulakry. Rzeczywistość nie istnieje, SIC, Warszawa.

Bednarska M., Gołembski G. (2012), Wspótczesne wyzwania dla gospodarki turystycznej, Zeszyty Naukowe 225, Wydawnictwo Uniwersytetu Ekonomicznego w Poznaniu, Poznań.

Cohen E. (2011), Zmieniające się oblicza współczesnej turystyki, Folia Touristica, nr 25(2), red. nauk. W. Alejziak, wydanie specjalne z okazji 35-lecia Wydziału Turystyki i Rekreacji AWF w Krakowie: „Z Warsztatów Mistrzów”, Kraków.

Franta A. (2004), Reżyseria przestrzeni. O doskonaleniu przestrzeni publicznej miasta, Seria Architektura, Monografia 309, Politechnika Krakowska, Kraków.

Gangewere R. J., Theme City: Imagining Pittsburgh, http://carnegiemuseums. org/cmag/bk_issue/1999/sepoct/feat6.html [dostęp 09.09.2014].

Giddens A. (2002), Nowoczesność i tożsamość, Wydawnictwo Naukowe PWN, Warszawa.

Herman K. (2011), Ogrody tymczasowe w przestrzeniach kolektywnych, praca doktorska, Wydawnictwo Sztuka Ogrodu Sztuka Krajobrazu Beata J. Gawryszewska, Seria Wydawnicza: Doktoraty Katedry Sztuki Krajobrazu SGGW Warszawa, http://www.youblisher.com/p/885064Ogrody-tymczasowe-w-przestrzeniach-kolektywnych [dostęp 01.12.2014].

Hughes H. (2003), Arts, Entertainment and Tourism, Butterworth-Heinemann, Oxford-Burlington. Jędrysiak T. (2008), Turystyka kulturowa, Polskie Wydawnictwo Ekonomiczne, Warszawa.

Kaczmarek J., Stasiak. A., Włodarczyk B. (2002), Produkt turystyczny albo jak organizować poznawanie świata, Wydawnictwo Uniwersytetu Łódzkiego, Łódź.

Kowalczyk A. (2000), Geografia turyzmu, Wydawnictwo Naukowe PWN, Warszawa.

Kowalczyk A. (2005), Nowe formy turystyki miejskiej, Prace i Studia Geograficzne, Tom 35, Warszawa.

Kruczek Z. (2012), Parki tematyczne jako flagowe atrakcje turystyczne. Rozwój i globalizacja, Turystyka Kulturowa, www.turystykakulturowa.org. nr 1/2012 (styczeń 2012).

Kurek W. (2007), Turystyka, Wydawnictwo Naukowe PWN, Warszawa.

Lorens P. (2006), Tematyzacja przestrzeni publicznej miasta, Wydawnictwo Politechniki Gdańskiej, Gdańsk.

MacCannell D. (2000), Turysta. Nowa teoria klasy próżniaczej, tłum. E. Klekot, WWL MUZA SA, Warszawa.

Mergler L., Pobłocki K., Wudarski M. (2013), Anty-Bezradnik przestrzenny: prawo do miasta $w$ działaniu, Biblioteka Res Publiki Nowej, Fundacja Res Publica, Warszawa.

Mikos v. Rohrscheidt A. (2008), Koordynacja turystycznych szlaków tematycznych-analiza wybranych systemów polskich i europejskich, Turystyka Kulturowa, www.turystykakulturowa.org nr 1/2012 (styczeń 2012).

Miles S. (2010), Space for consumption: pleasure and placelessness in the post-industrial city, SAGE Publications. 
Raszeja E. (2008), Krajobraz wiejski - wartość czy towar? Problemy promocji, komodyfikacji i autentyczności w projektowaniu zagospodarowania rekreacyjnego, Nauka Przyroda Technologie, $3,1, \# 36$.

Rzeńca P. (2012), Parki tematyczne jako czynnik rozwoju gospodarki. Identyfikacja zjawiska, [w:] Problemy rozwoju gospodarczego, E. Sobczak, A. Raszkowski (red.), Prace Naukowe Uniwersytetu Wrocławskiego nr 244, Wydawnictwo Uniwersytetu Ekonomicznego we Wrocławiu, Wrocław.

Rzeńca P. (2014), Themed facilities in Poland as a response to the economic crisis at the beginning of the 21st century, [w:] Local production systems and regional development, IEIE SB RAS, Ternopil National Economic University, University of Lodz, Novosibirsk-Sofia-TernopilLodz.

Sarzyński P. (2012), Wrzask w przestrzeni, Biblioteka Polityki, Warszawa.

Skonieczna K. (2007), Ogrody tymczasowe jako sposób poprawy jakości przestrzeni miejskiej. Monografia i projekt, praca magisterska pisana pod kierunkiem B. Gawryszewskiej na Wydziale Ogrodnictwa i Architektury Krajobrazu SGGW w Warszawie.

Słomka T., Kicińska-Świderska A. (2004), Geoturystyka - podstawowe pojęcia, Geoturystyka.

Stasiak A. (2009), Turystyka literacka i filmowa, [w:] Współczesne formy turystyki kulturowej, K. Buczkowska, A. Mikos v. Rohrscheidt (red.), AWF w Poznaniu, Poznań.

Tanaś S. (2006), Tanatoturystyka - kontrowersyjne oblicze turystyki kulturowej, Peregrinus Cracoviensis, Zeszyt 17, Kraków.

Theme index. (2011), The Global Attractions Attendence Report, TEA/AECOM.

Throsby D. (2010), Ekonomia i kultura, Narodowe Centrum Nauki, Warszawa.

Warszyńska J. (2006), Geografia turystyczna świata, Wydawnictwo Naukowe PWN, Warszawa.

Zuziak Z. K. (1993), New challenges for the revitalization and management of our urban heritage, [w:] Managing historic cities, International Cultural Centre, Kraków.

\title{
THEMATIZATION OF SPACE AS A MANAGEMENT METHOD FOR LOCAL DEVELOPMENT
}

\author{
(Summary)
}

The life space of a modern man, more than ever in history, is subject to thematisation processes, i.e. conscious and intentional giving to it architectural forms referring to the past and other civilizations, which can be associated with the creation of mass-market performance. Interpreting broadly thematisation processes, it can be assumed that it results in all the spaces that are characterized by the accumulation of specific attributes and objects connected by a common theme, created in order to perform their specialized functions or to obtain an aesthetisation effect and the enhancement of the space value.

Thematisation of space is also a form of response to the changing needs of today's tourism industry and tourists themselves. Developing since World War II global tourism product leads on one hand to the unification of tourist services and forms of tourism development, on the other hand, undergoes a continuous counter-process of the offer differentiation contributes to innovation and specialization and leads to the emergence of new forms of tourism, mostly of a thematic and specialized nature. This in turn stimulates the processes of transformation of space in the scope of interests and meeting the needs of visitors, which results in the development of a wide spectrum of thematic sites.

Appropriate targeting of the thematisation processes of space as well as thematisation of tourism can be a way for a more effective management of local development. A good example of the implementation of the broadly understood thematisation of space are among others actions of local 
authorities in the scope of establishing cultural parks. The requirements made to this kind of spatial conservation forms determine the local authorities to activities restoring its historical equipment and specificity, thus increasing tourist and economic attractiveness of the area as well as stimulating the sense of local identity of the local population and positively catalyze its activities for the sake of the development of the territory.

Key words: thematisation, thematic tourism, space, theme park, commodification. 